\title{
PREZENTACJE
}

\section{Badania z zakresu historii wychowania w Uniwersytecie Warmiń- sko-Mazurskim w Olsztynie}

Na mocy Ustawy z dnia 9 lipca 1999 roku został powołany w Olsztynie Uniwersytet Warmińsko-Mazurski, który jest kontynuatorem tradycji akademickiej trzech szkół wyższych: Akademii Rolniczo-Technicznej im. M. Oczapowskiego w Olsztynie, Wyższej Szkoły Pedagogicznej w Olsztynie oraz Warminskiego Instytutu Teologicznego.

Strukturę Uniwersytetu Warmińsko-Mazurskiego tworzy dwanaście wydziałów, w tym Wydział Pedagogiki i Wychowania Artystycznego, w ramach którego istnieja dwa zakłady zajmujące sie problematyka historii wychowania, rozważana jednakże w różnych aspektach. Sq to: Zakład Historii Wychowania, którym kieruje prof. dr hab. Andrzej Gassiorowski oraz Zakład Pedagogiki Historyczno-Porównawczej, którym kieruje prof. dr hab. Alicja Kicowska

Mimo, że Uniwersytet Warmińsko-Mazurski w Olsztynie zakonczyl dopiero pierwszy rok swojej działalności, to badania z zakresu historii wychowania w tym środowisku naukowym majq już swoją tradycje oraz określony dorobek naukowy. Prowadzili je badacze skupieni wcześniej w Zakładzie Historii Wychowania Wyższej Szkoły Pedagogicznej w Olsztynie oraz w Instytucie Nauk o Wychowaniu Akademii Rolniczo-Technicznej w Olsztynie.

Aktualnie badania realizowane w Zakładzie Historii Wychowania - bęđącym kontynuacja jednostki funkcjonującej $w$ byłej WSP - koncentrują się na dziejach myśli pedagogicznej i oświaty polskiej w regionie warminsko-mazurskim oraz na Litwie (1919-1940). W ramach tego problemu obecnie realizowane sq̨ następujące tematy cząstkowe:
- problematyka autochtonów na łamach wybranych czasopism w latach 1945-1949,

- nauczanie religii rzymsko-katolickiej w szkołach powszechnych,

- działalność polsko-katolickich towarzystw szkolnych na Warmii i Powiślu w latach 1919-1939 oraz towarzystw nauczycielskich w II Rzeczypospolitej,

- działalność organizacji harcerskich na Warmii i Mazurach w latach 1945-1956.

Zakład Pedagogiki Historyczno-Porównawczej - grupujący pracowników wywodzacych się z byłej ART - powstal w 1999 roku w ramach Instytutu Nauk o Wychowaniu Wydziału Pedagogiki i Wychowania Artystycznego. Zakres działalności badawczej tej jednostki wyznaczaja dotychczasowe zainteresowania naukowe pracowników oraz perspektywiczne plany badawcze, które najogólniej odzwierciedla nazwa Zakładu.

Dotychczasowy dorobek naukowy pracowników skoncentrowany był wokół następujących zagadnień:

- ideologii wychowawczej okresu międzywojennego,

- wychowania gospodarczego w II Rzeczypospolitej,

- wychowania rodzinnego w polskiej pedagogii XIX i XX wieku,

- dziejów nauczania historii wychowania w zakładach i uczelniach ksztalcących nauczycieli,

- historii edukacji rolniczej w ujęciu regionalnym, ogólnokrajowym i europejskim,

- edukacji ekologicznej,

- metodologii historii wychowania. 
Aktualnie finalizowane sq badania nad dziejami edukacji rolniczej na Warmii i Mazurach w XX wieku oraz analizą porównawcza szkolnictwa rolniczego w Polsce i we Francji. Obecnie, z uwagi na krótki jeszcze okres funkcjonowania Zakładu Pedagogiki Historyczno-Porównawczej, wypracowywany jest profil jego działalności naukowej. Zakłada się zorientowanie badań zwłaszcza na studia nad dziejami systemów edukacji zawodowej, rozpatrywanej w kontekście istotnych uwarunkowań społeczno-ekonomicznych oraz $w$ ujęciu komparatystycznym.

W omawianych zakładach badania $\mathrm{z}$ zakresu historii wychowania prowadzi trzech profesorów nadzwyczajnych, jeden doktor habilitowany, trzech doktorów, dwóch magistrów oraz trzech doktorantów. Dotychczasowa aktywność naukowa pracowników obu zakładów zaowocowała łączną liczbą około 300 publikacji. Wśród nich jest kilkanaście opracowań zwartych (naukowych i dydaktycznych) oraz ponad 200 artykułów i rozpraw opublikowanych w czasopismach i publikacjach zbiorowych. Wyniki badań prezentowane były też na różnych konferencjach naukowych w kraju i za granica.

Andrzej Gqsiorowski Alicja Kicowska

\section{Irena Sondecka - obrończyni polskości z obwodu tarnopolskiego na Ukrainie (z dziejów tajnej oświaty na sowieckiej Ukrainie po II wojnie światowej)}

Wielu Polaków na Ukrainie w okresie międzywojennym i powojennym przeżyło tragedie osobiste, ale dramatem wszystkich Polaków na tej ziemi było ciągłe i metodyczne unicestwianie ich kultury, oświaty, tradycji narodowych i religii. Problemy te poruszano już w publicystyce i literaturze naukowej, ale wiele zapewne będzie się jeszcze o tych zagadnieniach pisać. W niniejszym tekście postaram się tylko wyrazić osobiste refleksje na ten temat, jak również przytoczyć dane dotyczące patriotycznej działalności nauczycielki z Krzemieńca - Ireny Sondeckiej, działającej na rzecz zachowania polskości w tym mieście w okresie powojennym.

Żeby w pehni ocenić znaczenie tej działalności postaram się krótko przeanalizować problemy związane $\mathrm{z}$ historią szkolnictwa polskiego na Ukrainie sowieckiej.

Na podstawie danych spisu ludności (1970) na Ukrainie zamieszkiwało 295,1 tys. Polaków ${ }^{1}$. Diaspora polska wśród tzw. mniejszości narodowych zajmowała (po Rosjanach, Białorusinach i Żydach) pod względem liczebności czwarte miejsce. Należy sądzić, że od tamtego czasu zmniejszyła się diaspora żydowska z powodu wyjazdów dużej ilości przedstawicieli tej narodowości do krajów zachodnich. Liczba przedstawicieli innych narodowości (nie biorąc pod uwage zmian społeczno-politycznych po rozpadzie ZSRR), praktycznie nie zmieniła się. Odnośnie diaspory polskiej można stwierdzić, że zwiększyła się ona znacznie pod wpływem wzmożenia działalności ruchów narodowościowych pod koniec lat 80-tych, działalnosici organizacji polonijnych, odrodzenia świadomości narodowej Polaków. Zniknął też strach przed deportacjami znanymi $z$ okresu przedwojennego i powojennego, kiedy realnie grozily ,wywózki" za polskie pochodzenie. Uważam, że stan ilościowy mniejszości polskiej w obecnej sytuacji na Ukrainie pod wpływem m.in. wymienionych czynników znacznie wzrósł i przekracza 400 tys. osób.

W latach 70-tych, kiedy liczbę Polaków na Ukrainie oficjalnie szacowano na 300 tysięcy, 